\title{
One-Pot, Three-Component Synthesis of 1, 4-Dihydropyridines by Using Nano Crystalline Copper Ferrite
}

\author{
I. V. KASI VISWANATH* and Y. L. N. MURTHY \\ *Department of Chemistry, K L University, Vaddeswaram, Guntur Dist, India \\ Department of organic Chemistry, Andhra University, Visakhapatnam, India \\ viswanath_fed@kluniversity.in
}

Received 12 August 2012 / Accepted 4 September 2012

\begin{abstract}
Copper ferrite nano material (catalyst) are reusable heterogeneous initiator in the synthesis of 1, 4-dihydropyridines is presented. The reaction of substituted aromatic aldehydes, ethyl acetoacetate and ammonium acetate was achieved in presence of copper ferrite nano powders at room temperature in ethanol. The nano catalyst was easily recovered and its reusability was recorded.
\end{abstract}

Keywords: Nano copper ferrite, Heterogeneous initiator, 1, 4-Dihydropyridines, Reusable

\section{Introduction}

Heterogeneous catalysis results in easy separation and recycling of catalyst. Despite the advantages of homogeneous metal catalysts, difficulties in recovering the catalyst from the reaction mixture severely inhibit their use in industry. Recent reports reveal that magnetic nano particles are efficient catalysts and they can be easily separated from reaction mixture ${ }^{1}$. The high surface area to volume ratio of metal oxide nano particle is mainly responsible for their catalytic performance ${ }^{2}$. Copper ferrite nano material is one such reusable catalyst which shows profound catalytic activity in organic synthesis ${ }^{3}$. Ferrite is a family of oxide that plays an important role in the field of heterogeneous catalyst and proved to be a suitable support. Nickel ferrite with an inverse spinel structure showed ferromagnetism and therefore it can be easily separated from reaction mixture by employing an external magnetic field.

1,4-Dihydropyridines (DHPs), a class of drugs, are known for their calcium channel modulation. The DHP moiety is common to numerous bioactive compounds. These compounds have a remarkable significance because, of their wide range of pharmacological and biological activity such as cardiovascular diseases including hypertension ${ }^{4}$, anti-inflammatory ${ }^{5}$, antiviral $^{6}$, cytotoxicity ${ }^{7}$, anticonvulsants $^{8}$, antituberculosis ${ }^{9}$ antithrombotic ${ }^{10}$, in the treatment of Alzheimer's diseases ${ }^{11}$, calcium agonists and antagonists ${ }^{12}$, more recently as a enhancers of the vanilloid receptor 1 $(\mathrm{TRPV} 1)^{13}$ and screened as the human multidrug resistance protein ${ }^{14}$. Classically 1,4-DHPs 
are synthesized by Hantzsch reaction ${ }^{15}$ through cyclo condensation of aldehyde, ethyl acetoacetate and ammonium acetate in ethanol or in the presence of acetic acid at $80{ }^{\circ} \mathrm{C}$, which suffers from long reaction periods and low yields. From the last two decades this reaction was fine tuned with numerous methods and methodologies for the best yields and low reaction times and under neat conditions. While some of the methods involve in the synthesis of numerous biologically active 1,4-DHP analogues have allowed expansion of the quantitative structure activity relationship $(\mathrm{QSAR})^{16}$, from different substrates of $\beta$-dicarbonyl compounds ${ }^{17}$ (Acetyl acetone, dimedone, 1,3-cyclohexadione, ethyl acetoacetate and methyl acetoacetate), nitriles ${ }^{18}$, amides ${ }^{19}$ and acetylene esters ${ }^{20}$.

Gowaravaram sabita et al. ${ }^{21}$ studied the synthesis of various substituted Hantzsch 1,4dihydro pyridines using the classical Hantzsch procedure and modified Hantzsch conditions for the first time at room temperature in the presence of iodo trimethyl siliane (TMSI) generated in situ in $\mathrm{CH}_{3} \mathrm{CN}$, in excellent yields. An efficient and eco friendly synthesis of glycosyl 1,4-dihydro pyridines has been presented by Neetu Tewari et al. ${ }^{22}$. In this reaction, glycosyl 1,4-dihydro pyridines prepared by a three component reaction of $\beta$-ketoesters or ketones, enamines and glycosyl aldehydes in presence of tetra butyl ammonium hydrogen sulfate as a catalyst in diethylene glycol. Jung Hwan Lee ${ }^{23}$ described that Hantzsch 1,4dihydropyridines are prepared by fermenting baker's yeast with alkyl acetoacetate and ammonium acetate. $\mathrm{Yb}(\mathrm{OTf})_{3}$ catalyzed efficient Hantzsch reaction via four component coupling reactions of aldehydes, dimedone, ethylacetoacetate and ammonium acetate at ambient temperature was described by Li-Minwang et $a .^{24}$. Copper(II) triflate catalyzes efficiently in the three-component condensation of aldehydes $\beta$-ketoester and ammonium acetate in aceto nitrile at $25{ }^{\circ} \mathrm{C}$ to afford the corresponding Hantzsch 1,4 -dihydrophyrdines in high yields ${ }^{25}$. A simple inexpensive and efficient one pot synthesis of 1,4 dihydropyridine derivatives at room temperature using catalytic amount of iodine were reported with excellent yields and also an easy access to various substituted 1,4-dihydropyridines derivatives quantitatively using commercially available iodine as a catalyst ${ }^{26}$. Here in, we report nano copper ferrite as a reusable catalyst, in the synthesis of 1,4-dihydropyridines with shorter reaction times (than reported) in good to moderate yields. The general synthetic scheme is presented in Scheme 1

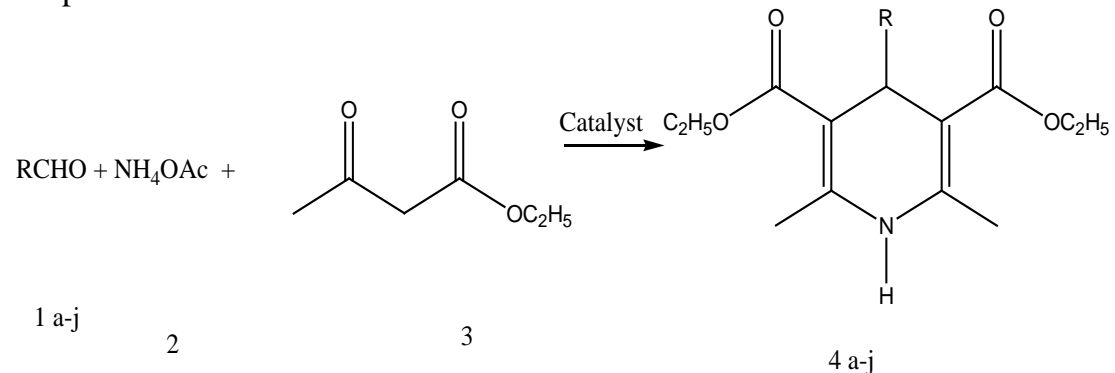

Catalyst: Copper ferrite (1 mole \%), $\mathrm{R}=$ a) $\mathrm{Ph}$, b) 4-MeoC $\mathrm{C}_{6} \mathrm{H}_{4}$ c) 4- $\mathrm{ClC}_{6} \mathrm{H}_{4}$ d) 4- $\mathrm{NO}_{2} \mathrm{C}_{6} \mathrm{H}_{4}$ e) 4$\mathrm{MeC}_{6} \mathrm{H}_{4}$ (f) 3- $\mathrm{NO}_{2} \mathrm{C}_{6} \mathrm{H}_{4}(\mathrm{~g}) \mathrm{n}-\mathrm{C}_{9} \mathrm{H}_{9}$ (h) 2- $\mathrm{NO}_{2} \mathrm{C}_{6} \mathrm{H}_{4}$ (i) 2-furyl (j) 2-MeoC $\mathrm{H}_{6} \mathrm{H}_{4}$

Scheme 1. Synthesis of 1, 4-dihydropyrines

\section{Experimental}

The catalyst was synthesized by citrate gel precursor method. Copper(II) nitrate and iron(III) nitrate were taken in stoichiometric proportions and minimum amount of deionized water was added to produce clear cationic solution. Citric acid solution was then prepared in stoichiometric 
ratio. Aqueous solutions with 1:1 molar ratio of metal ion solutions were mixed and citric acid was added in equimolar ratio to the above mixed metal ion solution. $\mathrm{pH}$ was adjusted to 7 by adding ammonia solution. The aqueous mixture was kept for stirring to form a highly viscous gel. The gel was then heated gradually up to $90{ }^{\circ} \mathrm{C}$ to evolve reddish brown gases and become dried gel which was finally treated at $350{ }^{\circ} \mathrm{C}$ for $1 \mathrm{~h}$ to observe whether the dry gel burnt out in self propagating manner to form loose powder. The finely powdered particles were calcinated at $600{ }^{\circ} \mathrm{C}$. The powder was then characterized.

\section{General synthesis of 1, 4 dihydro pyridines: $\mathbf{4 a}$}

To a stirred suspension of copper ferrite $(10 \mathrm{~mol} \%)$ in ethanol $(5 \mathrm{~mL})$ were added to an aldehyde (1 mmol) 1a-1j, ethyl acetoacetate $(2 \mathrm{mmol})$ and ammonium acetate $(1 \mathrm{mmol})$. After stirring and heating for specified time then the reaction was continued for a certain period of time (Table 1) as required for completion (monitored by TLC). The solvent was evaporated under reduced pressure. The reaction mixture was then filtered to separate the catalyst and the filtrate was quenched with a few drops of water and the product was extracted with ethyl acetate. The combined organic phase was washed with aq. $\mathrm{NaHCO}_{3}$ solution to remove acetic acid produced in the reaction, dried over anhydrous $\mathrm{Na}_{2} \mathrm{SO}_{4}$ and concentrated under reduced pressure. Further purification was attained by column chromatography, a colourless crystalline compound was formed and recrystalized from ethanol. The structure of the products (4a- $\mathbf{4 j}$ ) was confirmed by ${ }^{1} \mathrm{H} \mathrm{NMR},{ }^{13} \mathrm{C}$ NMR spectra and comparison with authentic samples prepared by reported methods.

Table 1. Synthesis of 1,4-dihydropyridines using copper ferrite nano particles

\begin{tabular}{cccc}
\hline S. No & $\mathrm{R}$ & Time, $\mathrm{h}$ & Yield \\
\hline 1 & $\mathrm{Ph}$ & 4.0 & 98 \\
2 & 4-MeoC $\mathrm{H}_{4}$ & 4.5 & 92 \\
3 & 4-ClC $\mathrm{H}_{4}$ & 4.0 & 85 \\
4 & $4-\mathrm{NO}_{2} \mathrm{C}_{6} \mathrm{H}_{4}$ & 4.5 & 85 \\
5 & $4-\mathrm{MeC}_{6} \mathrm{H}_{4}$ & 3.5 & 88 \\
6 & 3- $\mathrm{NO}_{2} \mathrm{C}_{6} \mathrm{H}_{4}$ & 4.5 & 80 \\
7 & ${\mathrm{n}-\mathrm{C}_{9} \mathrm{H}_{9}}^{2}$ & 10 & 65 \\
8 & 2- $\mathrm{NO}_{2} \mathrm{C}_{6} \mathrm{H}_{4}$ & 6.0 & 75 \\
9 & $2-$ furyl $_{10}$ & 4.5 & 87 \\
10 & 2-MeoC $6 \mathrm{H}_{4}$ & 4.5 & 85 \\
\hline
\end{tabular}

\section{Results and Discussion}

Diethyl 1, 4-dihydro-2, 6-dimethyl-4-phenylpyridine-3, 5-dicarboxylate, $4 a$

Yield: 98\%; colorless solid; m.p. $156{ }^{0} \mathrm{C}$ (crystallized from EtOH), IR (KBr): 500, 620, 1050 , 1100, 1180, 1200, 1500, 1667, 1690, 2350, 2867, $3440 \mathrm{~cm}^{-1} ;{ }^{1} \mathrm{H} \operatorname{NMR}\left(\mathrm{CDCl}_{3}\right): \delta 1.23$ (t, J=7.2Hz, 6H), 2.35(s, 6H), 4.09 (q, 4H), 4.97 (s, 1H), 5.7(brs, $1 \mathrm{H}), 7.08-7.26(\mathrm{~m}, 5 \mathrm{H}) ;{ }^{13} \mathrm{C}$ NMR $\left(\mathrm{CDCl}_{3}\right): \delta 14.28,19.23,39.59,59.56,103.92,126.06,127.89,144.10,147.61,167.54$.

Diethyl 1,4-dihydro-2,6-dimethyl-4-(4-methoxy- phenyl)pyridine-3,5-dicarboxylate, $\mathbf{4 b}$ Yield: 92\%; colorless solid; m.p. $194{ }^{\circ} \mathrm{C}$ (crystallized from EtOH); IR(KBr): 500, 700, 1000 , 1050, 1200, 1250, 1300, 1500, 1700, 2400, $3300 \mathrm{~cm}^{-1} ;{ }^{1} \mathrm{H} \quad \mathrm{NMR}\left(\mathrm{CDCl}_{3}\right): \delta 1.25$ (t, $J=7.1 \mathrm{~Hz}, 6 \mathrm{H}), 2.38(\mathrm{~s}, 6 \mathrm{H}), 3.94$ (s, 3H), 4.05 (q, $J=7.1 \mathrm{~Hz}, 4 \mathrm{H}), 4.87(\mathrm{~s}, 1 \mathrm{H}), 5.92(\mathrm{~s}, 1 \mathrm{H})$, 6.88(d, $J=8.7 \mathrm{~Hz}, 2 \mathrm{H}), 7.11(\mathrm{~d}, J=8.6 \mathrm{~Hz}, 2 \mathrm{H}) ;{ }^{13} \mathrm{C} \mathrm{NMR}\left(\mathrm{CDCl}_{3}\right): \delta 14.68,19.55,39.13$, 55.30, 59.85, 104.53, 113.62, 129.19, 140.79, 144.17, 158.30, 167.98. 
Diethyl 1,4-dihydro-2,6-dimethyl-4-(4-chloro-phenyl)pyridine-3,5-dicarboxylate, 4c

Yield: 85\%; color less solid; m.p.141-43 ${ }^{\circ} \mathrm{C}$ (crystallized from EtOH), IR (KBr): 500, 600, 1000, 1130, 1310, 1539, 1694, 2373, 2912, $3400 \mathrm{~cm}^{-1}$; ${ }^{1} \mathrm{H}$ NMR $\left(\mathrm{CDCl}_{3}\right): \delta 1.23$ (t, $J=7.2$ Hz, 6H), 2.30 (s, 6H), 4.29 (q, $J=7.2 \mathrm{~Hz}, 4 \mathrm{H}), 4.91$ (s, 1H), 5.86 (s, 1H), 7.26 (s, 4H);

${ }^{13} \mathrm{C}$ NMR $\left(\mathrm{CDCl}_{3}\right): \delta 14.22,19.10,39.19,59.57,103.58,127.85,129.22,131.69,144.20$, 146.31, 167.25.

Diethyl 1,4-dihydro-2,6-dimethyl-4-(4-nitro- phenyl)pyridine-3,5-dicarboxylate, 4d

Yield: 85\%; colorless solid; m.p. $127{ }^{\circ} \mathrm{C}$ (crystallized from EtOH), IR (KBr):600, 800, 1170, 1220, 1330, 1500, 1700, 2953, $3370 \mathrm{~cm}^{-1} ;{ }^{1} \mathrm{H}$ NMR $\left(\mathrm{CDCl}_{3}\right): \delta 1.25(\mathrm{t}, J=7.3 \mathrm{~Hz}$, 6H), 2.34 (s, 6H), 4.29 (q, J=7.3Hz, 4H), 5.05(s, 1H), 5.80(s,1H), 7.40(d, J=8.8 Hz, 2H), $8.06(\mathrm{~d}, J=8.1 \mathrm{~Hz}, 2 \mathrm{H}) ;{ }^{13} \mathrm{C}$ NMR $\left(\mathrm{CDCl}_{3}\right): \delta 14.17,20.57,40.94,59.95,102.52,124.28$, 145.16, 146.09, 157.16, 167.88 .

Diethyl1,4-dihydro-2,6-dimethyl-4-(4-methyl-phenyl)pyridine-3,5-dicarboxylate, $4 \boldsymbol{e}$

Yield: 88\%; colorless solid; m.p.160-61 ${ }^{\circ} \mathrm{C}$ (crystallized from EtOH); IR (KBr): 500, 1040, 1150, 1200, 1300, 1390, 1450, 1700, 2400, 2460, $3300 \mathrm{~cm}^{-1} ;{ }^{1} \mathrm{H} \mathrm{NMR}\left(\mathrm{CDCl}_{3}\right): \delta 1.23(\mathrm{t}, J=$ $7.2 \mathrm{~Hz}, 6 \mathrm{H}), 2.27(\mathrm{~s}, 3 \mathrm{H}), 2.30(\mathrm{~s}, 6 \mathrm{H}), 4.09(\mathrm{q}, J=7.2 \mathrm{~Hz}, 4 \mathrm{H}), 4.86(\mathrm{~s}, 1 \mathrm{H})$, 5.77(brs,1H),6.95(d, $J=8.1 \mathrm{~Hz}, 2 \mathrm{H}), 7.09(\mathrm{~d}, J=8.1 \mathrm{~Hz}, 2 \mathrm{H}) ;{ }^{13} \mathrm{C}$ NMR $\left(\mathrm{CDCl}_{3}\right): \delta 14.25$, 19.08, 20.98, 39.03, 59.46, 103.82, 128.44, 135.17, 144.10, 144.95, 167.59.

Diethyl 1, 4-dihydro-2,6-dimethyl-4-(3-nitro-phenyl)pyridine-3,5-dicarboxylate, $\mathbf{4 f}$ Yield: 80\%; ${ }^{1} \mathrm{HNMR}\left(\mathrm{CDCl}_{3}\right): \delta 1.22$ (t, $\left.J=7.3 \mathrm{~Hz}, 6 \mathrm{H}\right), 2.30$ (s, $\left.6 \mathrm{H}\right), 4.24$ (q, $J=7.8 \mathrm{~Hz}, 4 \mathrm{H}$ ),

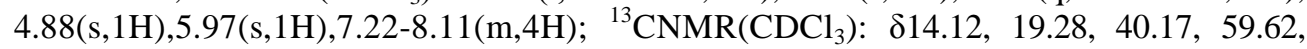
102.88,123.52,126.78,131.63,132.86,143.14,146.27, 148.55, 168.40.

Diethyl 1, 4-dihydro-2,6-dimethyl-4-nonylpyridine- 3,5-dicarboxylate, $\mathbf{4 g}$

Yield: 65\%; gum; ${ }^{1} \mathrm{H}$ NMR $\left(\mathrm{CDCl}_{3}\right): \delta 0.90$ (t, $\left.J=8.4 \mathrm{~Hz}, 3 \mathrm{H}\right), 1.25(\mathrm{~m}, 16 \mathrm{H}), 1.35$ (t, $J=$ $8.4 \mathrm{~Hz}, 6 \mathrm{H}), 1.45$ (m, 2H), 2.30 (s, 6H), 3.85 (m, 1H), 4.25 (q, J =8.6 Hz, 4H), 5.85 (br s, $1 \mathrm{H}) ;{ }^{13} \mathrm{C}$ NMR $\left(\mathrm{CDCl}_{3}\right): \delta 13.7,14.0,18.5,26.8,28.3,29.4,30.0,30.3,30.8,32.5,59.9$, 108.5, 141.2, 165.1.

Dimethyl 1, 4-dihydro-2,6-dimethyl-4-(2-nitro- phenyl)pyridine-3,5-dicarboxylate, $4 \mathbf{h}$ Yield: 75\%; colorless solid; m.p.172-73 ${ }^{\circ} \mathrm{C}$ (crystallized from EtOH),); IR (KBr): 757, 858, 1020, 1103, 1190, 1217, 1284, 1309, 1352, 1434, 1492, 1529, 1618, 1649, 1689, 3020, $3442 \mathrm{~cm}^{-1} ;{ }^{1} \mathrm{HNMR}\left(\mathrm{CDCl}_{3}\right): \delta 2.34(\mathrm{~s}, 6 \mathrm{H}), 3.79(\mathrm{~s}, 6 \mathrm{H}), 5.73(\mathrm{~s}, 1 \mathrm{H}), 5.87(\mathrm{~s}, 1 \mathrm{H})$, 7.21 - $7.30(\mathrm{~m}, 1 \mathrm{H}), 7.41-7.54(\mathrm{~m}, 2 \mathrm{H}), 7.66-7.70(\mathrm{~m}, 1 \mathrm{H}) ;{ }^{13} \mathrm{C} \mathrm{NMR}\left(\mathrm{CDCl}_{3}\right): \delta 19.0$, 34.29, 52.84, 103.0, 125.65, 126.88, 130.88, 132.70, 142.10, 145.42, 147.54, 167.62.

Diethyl 1,4-dihydro-2,6-dimethyl-4-(2-furyl)- pyridine-3,5-dicarboxylate, 4i

Yield: 87\%; colorless solid; m.p163-65 ${ }^{\circ} \mathrm{C}$ (crystallized from EtOH), ${ }^{1} \mathrm{H}$ NMR $\left(\mathrm{CDCl}_{3}\right)$ : $\delta 1.22(\mathrm{t}, J=8.2 \mathrm{~Hz}, 6 \mathrm{H}), 2.30(\mathrm{~s}, 6 \mathrm{H}), 4.30$ (q, $J=8.2 \mathrm{~Hz}, 4 \mathrm{H}), 5.10$ (s, $1 \mathrm{H}), 5.90$ (br s, $1 \mathrm{H}$ ), $6.80-7.05(\mathrm{~m}, 3 \mathrm{H}) ;{ }^{13} \mathrm{C}$ NMR $\left(\mathrm{CDCl}_{3}\right): \delta 13.7,18.0,31.2,59.9,100.6,105.7,110.6$, 141.2, 142.7, 152.5, 165.0 .

Diethyl 1, 4-dihydro-2,6-dimethyl-4-(2-methoxy-phenyl)pyridine-3,5-dicarboxylate, $\mathbf{4} \boldsymbol{j}$

Yield: 85\%; colorless solid; m.p.141-43 ${ }^{\circ} \mathrm{C}$ (crystallized from EtOH), ${ }^{1} \mathrm{H}$ NMR $\left(\mathrm{CDCl}_{3}\right)$ : $\delta 1.25$ (t, $J=8.2 \mathrm{~Hz}, 6 \mathrm{H}), 2.35(\mathrm{~s}, 6 \mathrm{H}), 3.90$ (s, 3H), 4.10 (q, $J=8.2 \mathrm{~Hz}, 4 \mathrm{H}), 5.30(\mathrm{~s}, \mathrm{H})$, 5.80(brs, $1 \mathrm{H}), 6.80(\mathrm{~d}, J=8.7 \mathrm{~Hz}, 2 \mathrm{H}), 7.4(\mathrm{~d}, J=8.7 \mathrm{~Hz}, 2 \mathrm{H}) ;{ }^{13} \mathrm{C} \mathrm{NMR}\left(\mathrm{CDCl}_{3}\right): \delta 14.55$, 19.45, 39.33, 57.32, 59.80, 104.56, 115.61, 128.20,141.21, 144.23, 158.34, 167.77. 
In a typical experiment aldehyde, ethyl acetoacetate and ammonium acetate are mixed in presence of catalytic amount of copper nano ferrite in stoichiometric portions using ethanol as solvent and stirred at room temperature. The completion of the reaction was monitored by thin layer chromatographic technique ( $n$-hexane and ethyl acetate as elute). In our initials efforts to optimize the reaction condition, we screened various solvents like dichloromethane and acetonitrile for this reaction. We found the reaction was efficient in ethanol compared to the other solvents tested. The results are listed in Table 2. From Table 2 it is clearly evident that a significant decrease in yields and longer reaction times are noted for the solvents other than ethanol, where as in the presence of ethanol the yields are promising and shorter reaction times were noted.

Table 2. Synthesis of 1,4-dihydropyridines under different solvent systems

\begin{tabular}{ccccc}
\hline S.No. & Catalyst & Solvent & Time, $\mathrm{h}$ & Yield \\
\hline 1 & $\mathrm{CuFe}_{2} \mathrm{O}_{4}$ & Ethanol & 4.5 & 95 \\
2 & $\mathrm{CuFe}_{2} \mathrm{O}_{4}$ & Aceto nitrile & 6 & 75 \\
3 & $\mathrm{CuFe}_{2} \mathrm{O}_{4}$ & Dichloromethane & 12 & Trace \\
\hline
\end{tabular}

After completion of the reaction, the catalyst was recovered by magnetization and washed with diethyl ether and the recovered catalyst was reused for few more cycles. During washing with the solvent, it is clearly evident that there was no leaching of catalyst and was confirmed by performing the reaction with the filtrate. Atomic absorption spectroscopy was employed to determine the copper content of copper ferrite nano particles and it was found to be $24.7 \%$. The leaching of metal after three cycles was found to be $0.156 \%$. From our investigations, we observed that nano catalyst shows excellent to good reactivity with promising yields even for the next three cycles in the same reaction. Since, there was no observable loss in the yield percentage; the further reusability of nano catalyst was regretted. The results are listed in Table 3

Table 3. Reusability of nano catalyst

\begin{tabular}{ccc}
\hline S.No & Catalyst recovery $^{\mathrm{a}}, \%$ & Yield $^{\mathrm{b}}, \%$ \\
\hline 1 & & 98 \\
2 & 95 & 92 \\
3 & 87 & 85 \\
4 & 85 & 80 \\
\hline
\end{tabular}

a: Catalyst recovered by membrane filtration and washed with diethyl ether and then by distilled water, $b$ : yields compared to isolated products

XRD studies were carried out to the above nano ferrite and XRD spectrum is presented in Figure 1. From the XRD data it is observed that the copper ferrites are spinal crystals. From the XRD data, size of the copper ferrite particles was calculated by using sheerer formulae \& particle size was found to be $20 \mathrm{~nm}$. This shows that the synthesized powder has nano size crystalline. The scanning electron microscope studies were carried out on the copper ferrite sample at $400{ }^{\circ} \mathrm{C}$ and it is presented in Figure 2. The lump size with irregular morphology was observed and it was found at $400 \mu \mathrm{m}$ at $400{ }^{\circ} \mathrm{C}$. From the above study we observed it posses less number of pores with smaller lump size, resulting fine grained micro structure with respect to ferrites. 


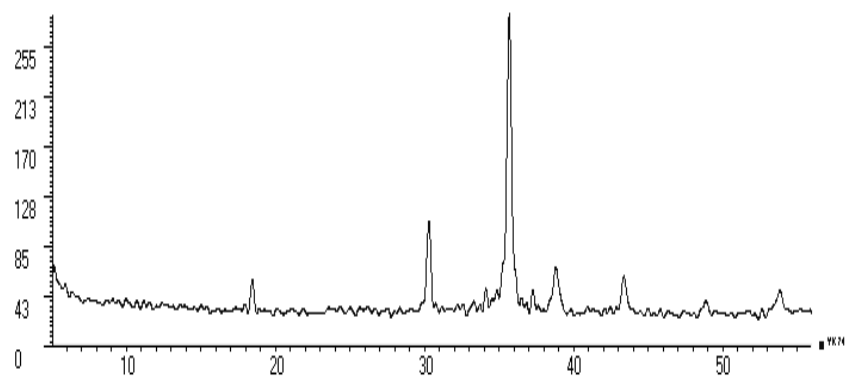

Figure 1. XRD Spectrum of $\mathrm{CuFe}_{2} \mathrm{O}_{4}$ at $400{ }^{\circ} \mathrm{C}$

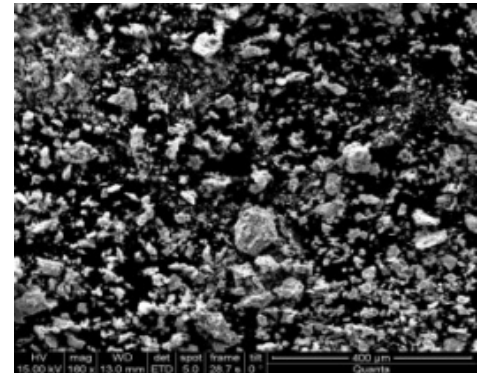

Figure 2. SEM image $\mathrm{CuFe}_{2} \mathrm{O}_{4} 400{ }^{0} \mathrm{C}$

\section{Conclusion}

We have reported an efficient procedure for the synthesis of 1, 4-dihydropyridines using copper ferrite catalyst as a reusable, non-toxic, non-corrosive, inexpensive and commercially available heterogeneous catalyst. The method also offers some other advantages such as clean reaction, low loading of catalyst, and high yields of products, short reaction times and use of various substrates, which make it a useful and attractive strategy for the synthesis of 1, 4-dihydropyridines.

\section{References}

1. (a) Yoon T J, Lee W, Oh Y S and Lee J K, New J Chem., 2003, 27, 227-229;

(b) Stevens P D, Fan J, Gardimalla H M R, Yen M and Gao Y, Org Lett., 2005, 7, 2085;

(c) Stevens P D, Li G, Fan J, Yen M and Gao Y, Chem Commun., 2005, 4435-4437.

2. Bell A T, Science, 2003, 299, 1688.

3. Kantam M L, Yadav J, Soumi L, Srinivas P, Sreedhar B and Figueras F, J Org Chem., 2009, 74(12), 4608-4611.

4. $\quad$ Scriabine A, J Cardiovasc Pharmcol., 1987, 9, S3-S7.

5. Briukhanov V M and Zverev-laf Elkin V I, Exp Clin Pharmacol., 1994, 57, 47-49.

6. Hilgeroth A and Lilie H, Eur J Med Chem., 2003, 38(5), 495-499.

7. Prashantha Kumar B R, Pankaj Masih, Karthikeyan E, Ankur Bansal and Suja Vijayan Pottekad, Med Chem Res., 2010, 19, 344-363.

8. Tusell J M, Barron S and Serratosa J, Brain Res., 1993, 622, 99-104.

9. Wachter G A, Davis M C, Martin A R and Franzblau S G, J Med Chem., 1998, 41, 2436-2438.

10. Cooper K, Fray M J, Parry M J, Richardson K and Steele J, J Med Chem., 1992, 35(17), 3115-3129. 
11. Choi S J, Cho J H, Im I, Lee S D, Jang J Y, Oh Y M, Jung Y K, Jeon E S and Kim Y C, Eur J Med Chem., 2010, 45(6), 2578-2590.

12. Schramm M, Thomas G, Towart R and Franckowiak G, Nature, 1983, 303(5917), 535-537.

13. Roh E J, Keller J M, Olah Z, Iadarola M J and Jacobson K A, Bioorg Med Chem., 2008, 16(20), 9349-9358.

14. Sirisha K, Chandra Shekar M, Umasankar K, Mahendar P, Sadanandam A, Achaiah G and Malla Reddy V, Bioorg Med Chem., 2011, 19, 3249-3254.

15. Hantzsch A and Liebigs J, Ann Chem., 1882, 215, 1.

16. Mathura V S, Patel N, Bachmeier C, Mullan M and Paris D, Bioinformation, 2010, 5, 122-127.

17. a) Wang X S, Shi D Q and Tu S J, Synth Commun., 2002, 32, 3449; b) Safari J, Banitaba S H and Khalili S D, J Mole Catal A Chem., 2011, 335, 46; c) Safari J, Banitaba S H and Khalili S D, Chin J Catal., 2011, 32(12), 1850-1855.

18. Kumar A and Sharma S, Green Chem., 2011, 13, 2017.

19. Wang J L, Liu B K, Yin C, Wu Q and Lin X F, Tetrahedron, 2011, 67(14), 2689-2692.

20. Jiang H, Mai R, Cao H, Zhu Q and Liu X, Org Biomol Chem., 2009, 7, 4943-4953.

21. Gowravaram Sabitha, Kiran Kumar Reddy G S, Srinivasa Reddy Ch and Yadav J S, Tetrahedron Lett., 2003, 44, 4129-4131.

22. Neetu Tiwari, Namrata Dwivedi and Rama P. Tripathi, Tetrahedron Lett., 2004, 45, 9011-9014.

23. Jung hwan Lee, Tetrahedron Lett., 2005, 46, 7329-7330.

24. Li-Min wang, Jia Sheng, Liang Zhang, Jian - Wei Han, Zhao-Yu Fan, He Tian and Chang-Tao Qian, Tetrahedorn, 2005, 61, 1539-1543.

25. Shengkai Ko and Ching-Fa Yao, Tetrahedron, 2006, 62, 7293-7299.

26. Abhimanyu S Paraskar and Arumugam Sudalai, Indian J Chem., 2007, 46B, 331-335. 